\title{
The Role of Civil Society and Participatory Governance in Japanese Democracy
}

\author{
Citizen Activities and the Concept of a Citizen Municipality
}

This article examines how citizen activities and participation in local communities have contributed to the innovation of the democratic system in Japan. It considers some of the problems related to the strengthening of civil society. By strengthening civil society, a new balance among the three sectors of civil society, government, and the market can be attained according to the notion of participatory governance. The first part of this article examines the activities of Seikatsu Clubs, consumer cooperatives, and workers' collectives as examples characteristic of civil society in Japan. The second part takes up the decentralization reforms of the municipalities and focuses on the concept of citizen municipalities as a form of local governments relying on the active engagement of their citizens. A stronger civil society sector, the reform of the system of self-governing municipalities, and the expansion of citizen participation affect innovation in Japanese democracy.

KEYWORDS: civil society, participatory governance, workers' collectives, citizen municipality and democracy

Minoru Tsubogo is a Professor at Waseda University (tsubogo@waseda.jp). His research focus is comparative politics, especially environmental governance and civil society in Japan and Germany. The author wishes to thank Profossor Mari Miura for the invitation to contribute this article, the readers who provided valuable comments on earlier versions of the text, and $\mathrm{Mr}$. Jens Bartel. 
IN THE ONGOING DEBATE on innovation in governance in the context of new developments in democracy, citizen participation is a key concept. Prior studies have emphasized the importance of citizen participation in elections on the one hand, but even more so of citizens directly engaging in the process of policy formation, decision-making, implementation, and evaluation (TsubOGO 2009, 3-4; HoECKer 2006, 3-6). Japan is considered to be currently undergoing a transformation from a democracy under "administrative guidance" to a democracy based on principles of citizens' self-governance. The discussion herein examines how citizen activities and participation in local communities have contributed to the innovation of the democratic system in Japan to date. Innovation in the democratic system in this context refers to the enactment of innovative means of governance and policy formation via initiatives, referendums, deliberations, and citizen activities, thereby strengthening the democratic process and the democracy as whole. This topic is reviewed in the context of a number of examples, and considers some of the problems related to the strengthening of civil society in Japan. The following sections outline how a stronger civil society sector, the reform of the system of self-governing municipalities, and the expansion of citizen participation affect innovation in Japanese democracy.

Under the coalition government of the Liberal Democratic Party and New Kōmeito before 2009, the discussion on establishing and maintaining an infrastructure for civil society centered on two principle objectives: first, that of increasing the efficiency of municipal administration, and second, the promotion of citizen participation. From 2009 to 2012, when the Democratic Party of Japan was in power, the same issue was discussed within the newly-established Council on the Promotion of the New Public Commons. The notion of a New Public Commons was built on the idea that citizens and the various actors of civil society, government, and the market should participate and assume responsibilities in public policymaking and in developing solutions for social problems (TsuBOGO 2011a, 24-25).

Section 1 of this article examines participatory governance and the civil society sector in present-day Japanese society from a number of angles. The contribution of civil society to the innovation of the democratic system in Japan is considered, as well as the broader question of how the relationships among the three sectors of civil society, government, and market are affected. In Section 2, the discussion turns to the activities of Seikatsu Clubs, consumer cooperatives, and workers' collectives, as examples characteristic of civil society in Japan. Although the Japanese word seikatsu 
corresponds to the English living, "Seikatsu Clubs" are local citizen groups for social engagement in the fields of nutrition, welfare, and environment. In this context, seikatsusha (seikatsu + sha, or "person") refers to citizens who in their daily lives engage in various local initiatives. Workers' collectives are frameworks in which members voluntarily invest, work, and manage their efforts independently, with the goal of instituting new mechanisms of employment.

Section 3 takes a closer look at the decentralization reforms of the municipalities (cities, towns, and villages), with a focus on the concept of citizen municipalities (corresponding to the term Bürgerkommune in German social sciences) as a form of local government relying on the active engagement of its citizens (Tsubogo 2007; Tsubogo, FoljantyJost, and AgATA 2009). Here, emphasis is placed on the principles of civil society and the capacity of providing solutions to citizens' needs (SUDA $2005,4)$. By considering examples of how citizens are putting citizen self-governance into practice (Section 2), and how municipality reforms aim to achieve a citizen municipality (Section 3 ), it becomes possible to discuss with greater comprehension the role of grassroots movements and citizen participation in the innovation of the democratic system in Japan.

\section{Participatory Governance and Civil Society in Japan}

In the discourse on citizen participation and democracy, direct democracy, deliberative democracy, and civil society democracy have been extensively discussed as three principle concepts of participatory governance (YAMAGUCHI 2004; Shinohara 2004; Hoecker 2006; Kersting 2008; SHINOHARA 2012; NANZ and Fritsche 2012). The author has also emphasized the aspect of participatory governance (TsuBOGO 2006; TsuвOGO 2011a).

The concepts of participatory governance and the civil society sector go beyond the conventional distinction of public vs. private (for example, the often-used phrase "from government to governance"). Scholars have advanced the idea of governance where policy problems are solved by reliance on the interaction of the three sectors of civil society, the government, and the market (Kooimann 2002; Tsubogo 2006; BenZ and PAPAdopouLOS 2006; Tsubogo 2011a), in a more complex relationship. The reorganization of government responsibilities thus is crucial to the management of this type of governance.

One reason for the concept of participatory governance receiving increased attention in recent years is the global trend toward the cur- 
rent complex type of urban society, with its accompanying proliferation of services, information, and related information technology. Throughout Japanese society, one witnesses changes to traditional family structures resulting from individualization, as well as the transformation of the employment system due to the emergence of various new forms of employment, and an increasing diversification of values and lifestyles. The consequent social exclusion and new poverty lines have become major problems. In this type of society, as it is difficult for government and market sectors alone to play the role of problem solver, new social movements with a stronger focus on the individual have appeared, and citizen activities have emerged as an organized way of attending to the problems of local communities. These movements, which first surfaced in Japan during the 1970 and 1980s, and have continued to gain in importance to the present time, have been variably described using terms such as "the nonprofit sector" and "citizen activities." Since the 1990s, this new resulting sector has come to be referred to as "the civil society sector."

Some examples of these various trends in citizen activities include: 1) consumers' cooperatives; 2) non-governmental organizations (NGOs) active in the field of international cooperation; 3 ) the "new wave of volunteering" (volunteering for self-actualization), a movement that started in the 1980s, breaking with prior modes of voluntary social service activities; 4) diverse citizen groups with a focus on welfare or environmental issues in local communities; 5) community businesses, NPO banks (banks for nonprofit organizations), and social enterprises such as workplaces for people with disabilities, etc.; 6) disaster-rescue volunteering; 7) NPOS tackling the problems of social exclusion and poverty, such as providing support for the homeless; 8) NPOS working on policy advocacy, such as information disclosure and climate protection; 9) trade unions engaged in welfare activities for workers; 10) the social contribution activities of companies; and so on (Tsubogo 2011a, 25-33, 40-46).

Related to the notion of participatory governance is its emphasis on a strong civil society sector. By strengthening civil society, a new balance among the three sectors of civil society, government, and the market can be attained. In past years, debate on decentralization reforms has focused on possible improvements in terms of efficiency of administration. Aligned with the principle of subsidiarity, another goal is to allow municipalities to redistribute financial resources and thereby achieve a higher degree of self-governance. Subsidiarity here refers to the principle that the responsibility for problems that can be solved locally also in practice remains at the local level. 
Ideally, the civil society sector is characterized by a discernible degree of solidarity, empathy, confidence, innovation, and criticism. Regarding the development of democracies, scholars have pointed out the important role of social capital in local communities, particularly social trust, norms of reciprocity, and networks of civic engagement (PUTNAM 1993; 2000). Citizen activities and the various groups within civil society accumulate social capital in local communities, and provide the communities with various services required by the citizens. In addition, they need to engage in the field of policy advocacy in order to achieve system improvements, and to provide new policy and system proposals.

The activities of community businesses and social enterprises represent an intermediary field between the civil society sector and the market sector. Between civil society and government, particularly at the municipal level, and in fields such as welfare, the environment, and culture and sports, the trend so far has been toward the outsourcing of services, facilities administration through a designated administrator system, and publicly built, but privately operated, citizen activity support centers. The latter, for instance, are facilities provided by the municipalities, and managed by NPOs. Municipalities have been criticized for subcontracting this service to NPOS, and the relationships between them have come under public scrutiny. Concerning participatory governance, there are various issues in need of careful consideration: for instance, the problem of the possible circumvention of elected municipal assemblies due to the interference of experts and citizen participation, or because of confrontation from experts and citizens. This, of course, relates to questions of the democratic legitimacy of participatory governance.

Since the end of the 1990s, major system reforms have been enacted for establishing and maintaining an infrastructure for the civil society sector in Japan. First, in March 1998, the Law to Promote Specified Nonprofit Activities (NPO Law) was established and a corresponding specified nonprofit activities corporation system was introduced. Prior to this, citizen activities organizations had generally been conducting their activities as voluntary groups; under the new framework, it became relatively easy to establish small-scale NPO corporations. As of September 30, 2013, the number of specified NPO corporations (ninsho NPO) had reached 48,244 (https://www.npo-homepage.go.jp/portalsite/syokatsutyobetsu_ninsh ou.html). Nevertheless, as of November 8, 2013, out of that number, those that had adopted the current NPO taxation system accounted for only 276 , with 169 approved specified (nintei NPO), and 107 temporarily approved 
specified (https://www.npo-homepage.go.jp/ portalsite/ninteimeibo .html).

Second, following the reforms of the public interest corporation system in 2008, a shift occurred from "public interest through approval of government agencies" to "public interest through the private sector" (YAmaOKA 2011, 52-57). The Public Interest Commission is responsible for the recommendation of approval of public interest corporations. Through these reforms, the legal frameworks for nonprofit and public interest activities were separated, and the respective organizations now had a choice between constituting themselves as general corporations, or NPO corporations, in their pursuit of nonprofit activities.

Third, following the revision of the NPO Law (April 1, 2012), a new donation taxation policy was introduced and wide-ranging reforms to the citizens' public interest taxation system were carried out. While on the one hand NPO banks provided financing to other NPOs, on the other hand, there is also a trend to establish mechanisms of mediation, such as incorporated foundations, between NPOs and the people making donations. Conscious efforts are being made to stimulate the circulation of citizens' capital in local communities. The new donation taxation system is thus bound to become the foundation on which these mechanisms are built.

The following section examines the expansion of the Seikatsu Club movement in various fields within local communities since the 1970s, and of workers' collectives that originated in these cooperatives.

\section{Seikatsu Club Consumer Cooperatives and Workers' Collectives}

\section{SEIKATSU CLUB COOPERATIVES AS SOCIAL MOVEMENTS}

Seikatsu Club cooperatives first appeared in Tokyo in the late 196os with the purpose of purchasing milk collectively, and soon spread into the Kanagawa and Kanto regions. The Seikatsu Clubs are built on relationships of solidarity among their participants (seikatsusha). For their economic activities, they rely on the corporate system for consumer cooperatives, with their activities run mainly by female club members. The Seikatsu Clubs' goal is to grow into a social movement. Within the clubs, groups of about ten people constitute units called han, which collect advance orders and make joint purchases of food, groceries, and everyday products. In addition, to provide a measure of food safety to their members, they cooperate directly with producers who disclose where, by whom, and by what methods the goods are produced and processed, including organic farm 
products and groceries with no artificial additives or chemical preservatives. Considering these activities, Seikatsu Clubs can be characterized and discussed as an autonomous, grassroots citizens' movement.

The scope of the Seikatsu Clubs' activities was originally limited to the field of food and the consumption of everyday goods; however, it has since expanded into new areas, including efforts to tackle environmental and welfare problems, the rights of children, gender problems, and international exchange. Also, the Seikatsu Clubs initiate and manage mutual aid and welfare projects, including, for instance, the Kanagawa Welfare Club Cooperative, as described below. The Seikatsu Club movement can be categorized as being part of the "citizens' capital segment," as distinguished from "industrial capital" and "tax capital." Hence, the expansion of the citizen capital segment leads to relatively weaker "industrial capital" and "tax capital" segments. It is therefore possible to argue that the growth of citizen capital through the activities of the Seikatsu Club cooperatives creates a new balance among citizen, industrial, and tax capital (MrYagI 2003; ҮокотА 2002).

The Seikatsu Club of the Kanto metropolitan area consists of four large cooperatives (Tokyo, Kanagawa, Saitama, and Chiba). According to the Joint Buying Movement Research Group, an initiative of the Seikatsu Club Kanto Regional Collective, "Seikatsu Clubs have succeeded in using the group system to achieve organizational management through participation and cooperation of each of their members, as their main actors, and through mutual assistance and shared development." Seikatsu Clubs are "places to realize the connection between democracy and a citizens' selfgoverning society" (Seikatsu Club 2013, 1). Moreover, Seikatsu Clubs promote their activities under the banner of "changing people's way of life" within a market society. As such, they aim to offer "alternatives to the traditional, gender-biased ways of conducting labor and politics" (SEIKaTsu Club 2013, 39).

Seikatsu Clubs have expanded in three directions. First, community businesses have been established and expanded to meet the various needs of citizens. This includes the formation of workers' collectives to independently conduct community work represented by alternative methods of employment. Second, to advance citizen self-governance at the municipal level, Seikatsu Clubs have engaged in policy advocacy activities for food safety, environmental issues, and town planning. The formulation of direct demands in a number of municipalities has resulted in the enactment of various ordinances, including a food safety ordinance. Third, Seikatsu Clubs advocate sending delegates to local councils; to this end, a local 
political party, Seikatsusha Networks, has been founded. However, this political party operates independently of any of the Seikatsu Clubs in the Kanto metropolitan area.

The various organizations mentioned above mutually cooperate with each other as parts of the Seikatsu Club movement. In this sense, the Seikatsu Club movement constitutes an innovative framework for action, while continuously expanding within local communities.

Seikatsu Club cooperatives follow the model of a decentralized organization. The joint retail activities of its members concentrate on three mechanisms for the delivery of goods: han delivery (home delivery exclusive to han members), the depot (a type of community store), and home delivery. Since 2004, the Kanagawa Seikatsu Club cooperative has consisted of five regional entities: Yokohama North, Yokohama South, Kawasaki, Shonan, and Sagami. The Kanagawa Depot started in 1982 as a joint market and community meeting place, and by 2013 , it had twenty-one branches. Its sales floors are run by workers' collectives. The depots coordinate and cooperate with day care providers, etc., and constitute important local venues. Participation in home delivery is also rising; in 2005, subscribers of the home delivery service of the Seikatsu Club's four cooperatives in the Kanto area constituted more than half its overall membership. Seikatsu Clubs thus aim to constitute "schools of democracy," e.g. by their "implementation of local initiatives by female citizens," and by putting democracy into practice in local communities (Seikatsu Club 2013, 41).

\section{WORKERS' COLLECTIVES AND POLICY ADVOCACY ACTIVITIES}

The first of the so-called "workers' collectives" (WoCo), WoCo Ninjin (or "people"), was established in Kanagawa Prefecture in 1982. With the objective of creating a new mechanism of employment, its founding members' aim was to have the same people investing, managing, and working in a citizens' business that would provide meaningful services for its community. As there is currently no corporate body framework to allow investments suitable for this type of nonprofit activity, workers' collectives conduct their affairs as either voluntary groups without legal personality, NPO corporations, or joint enterprise cooperatives (based on the Small and Medium-Sized Enterprise Cooperatives Act). In 1995, the Workers' Collective Network Japan (WNJ) was established as a nationwide umbrella organization for WoCos.

The objectives of the WNJ are to increase the number of WoCos, to facilitate collaboration between them, to promote the idea of WoCos more widely in society, and to achieve the enactment of a workers' cooperative 
law. The "Objectives" section of the wNy's "Workers' Collective Values and Principles" states that "workers' collectives aim to cooperatively establish places of work within local communities, by citizens aiming for social and economic independence." The "Democracy" section specifies that "the collective shall be democratically managed according to the principle of 'one person, one vote,' and by reliance on small groups. Moreover, each person shall have their share in the management responsibility of the workers' collective [...]" (WNJ 2013, 66).

According to a survey by the wNJ, in 2011 the total balance of all of the businesses of the WoCos participating in the WNJ was 11.3 billion yen (WNJ 2013, 75-77). Furthermore, the findings indicated a total of 358 WoCos with 9,318 members, mostly listed in Hokkaido, Saitama, Kanagawa, Chiba, and Tokyo. Among them, 169 groups had no legal personality (47 percent), 128 were NPO corporations ( 36 percent), 58 were joint enterprise cooperatives (16 percent), and 3 belonged to other forms of organizations. As for types of services, these WoCos provided household assistance and nursing support (132 WoCos), food delivery ( 67 WoCos), outsourcing for cooperatives (6o WoCos), child raising (40 WoCos), transport assistance (23 WoCos), and other services. In terms of gender and age, 8,670 members were female (93 percent) and 648 male (7 percent), with 39 percent of the respondents in their fifties, 31 percent in their sixties, 21 percent in their forties, 7 percent in their thirties, and 2 percent between 10 and 29 years old. Forty-two percent of the respondents worked at the WoCos fewer than 40 hours per month, 26 percent worked 40-80 hours, 31 percent worked 80-20o hours, and less than 1 percent worked 200 hours or more. Finally, 75 percent of respondents earned less than 1.03 million yen a year, 7 percent earned 1.04-2 million yen, 3 percent earned 2-3 million yen, 5 percent earned 3-4 million yen, and less than 1 percent earned 4 million yen or more.

As of April 2013, the Kanagawa Workers' Collective Federation (WoCo Kanagawa Federation) consisted of 160 groups with 4,861 members. The total balance of all businesses of its members was about 5.6 billion yen (fiscal year 2012). The Federation has 11 main areas of activity, including household assistance, a nursing sector, a food service, and lunch-box deliveries (http://www.wco-kznzgawa.gr.jp/aboutrengo.html).

The Welfare Club cooperative in Kanagawa Prefecture was established as an offshoot of the Seikatsu Club in 1989, coinciding with the establishment of joint buying and home delivery services of groceries and everyday articles to its members. In its statement of purpose, the Welfare Club declares that "rather than public welfare services provided by the state, municipalities, or private welfare services, which require payment with money, the 
WoCo aims to provide a new choice of services based on the principle of mutual help" (WoCo Kanagawa and Fukushi Club 2008, 19).

Currently, the Welfare Club cooperatives are engaged in a variety of activities, including the provision of a cooperative purchase system with home deliveries, a health and medical treatment network system, senior citizen housing with care services, and a welfare facilities network service. Together with the WoCos, they are establishing a residential welfare support system. In addition, the Welfare Club runs services in the nursing care insurance system, an outsourcing business mainly catering to the municipalities, as well as business to support people with disabilities. As of May 2013, Welfare Club cooperatives have spread across 23 municipalities and administrative districts within Kanagawa Prefecture, with members in 16,00o households, and a total business balance of 3.44 billion yen (http:// www.fukushi-club.net/gaiy ou/index.html; ttp://www.fukushi-club.net/w_ co/guide_w/guide.html).

Alongside the WoCo Kanagawa Federation, the NPO Corporation Workers' Collective Association (WoCo Association) was established in 2004 as a new "intermediary support organization," aiming to "contribute solutions to local communities through an association of nonprofit cooperatives" (ОKADA 2013, 208). While the main purpose of the Federation is training for the management of participation-type organizations, and providing business and legal consultation, the objectives of the WoCo Association mainly center on policy advocacy. In the WoCo Kanagawa Federation, training is stressed as "shared development," that is, "acquiring strength, growing together, and pooling the expertise and experiences of its participants" (OKADA 2013, 210).

Although most WoCo employees are women, these workplaces are based on the philosophy of being venues for "everybody to work together," regardless of gender, as well as to provide a place of work for the socially disadvantaged, such as people with disabilities, and unemployed young people. In 2005, the WoCo Association conducted a survey of employment conditions for people with disabilities in order to develop ways to better support their situations. This survey established that fifty-four people with disabilities had participated in the practical training and work initiatives of twenty-seven WoCos. The WoCos provide various forms of training, such as for full WoCo membership, part-time jobs, and volunteer work. Since the time of the survey, the WoCo Association has also assumed the role of coordinator for practical training and employment options for young people and people with disabilities. Yokohama City and Kanagawa Prefecture have outsourced to the WoCo Association various training projects 
for people with intellectual disabilities, and introduced initiatives such as the Yokohama Support Station for Young People, with the aim of coordinating practical training for young people.

Apart from this, the WoCo Association has also independently launched a store for making and selling lunch and dinner boxes, conceived as a place for people with disabilities and young people to work and train, and to participate in a communal working environment. However, the WoCo Association is aware of the need for a support system for these sorts of projects in order to sustain them continuously (OKADA 2013, 211-17). Precedents of such a support system include the B-type cooperatives in Italy, and the social enterprise movement based on the Social Enterprise Promotion Law in South Korea (2008). Examples of similar support systems can also be found in some municipalities in Japan.

In addition, the WoCo Association runs the Yokohama Personal Support Service as an intermediary employment model business and as part of its outsourcing work for Yokohama City. This particular project was initiated by the Cabinet Office in the 2012 fiscal year (OKADA 2013, 221). As of March 2012, there were seventy-six educational establishments for the practical training and employment support of disadvantaged groups. A total number of 215 people have completed practical and social training, out of which forty found employment (ten people with disabilities and thirty young people; ОKADA 2013, 218).

While WoCos have mainly served women as venues to invest, manage, and work, they also provide people with disabilities and young people with choices for a model of employment adapted to their needs. They function as intermediary places of employment, and provide their members with support toward their social independence. Yuriko Okada, Secretary General of the WoCo Association, noted that "we want to create a model, and quickly begin with the preparations for the next stage" (OKADA 2013, 221-24).

As mentioned before, the WoCo Association is active in the field of policy advocacy, rallying, for instance, for the enactment of a social business establishment promotion law. The WoCo Association has advocated a workers' collective bill that would allow the recognition of the legal personality of workers' collectives, and campaigned for the enactment of a cooperative labor law. ${ }^{1}$ Currently, Seikatsu Club cooperatives in the Kanto area are equally involved in the promotion of food safety, renewable energy,

1. Although outside the scope of this article, the WoCo Kanagawa Federation has advocated within its reports that citizens' labor, as a workers' collective way of working, be viewed as different from employment labor or housework labor (IsHIGE 2011). 
and a new system of social welfare. Through their motions for new policies and municipal ordinances, Seikatsu Clubs affect other groups and citizens as well, and thereby contribute substantially to the process of innovation within the democratic structures of Japanese local communities.

\section{Citizen Municipalities and Municipality Reform}

\section{THE CONCEPT OF A CITIZEN MUNICIPALITY}

As seen in the preceding section on workers' collectives, citizen activities contribute new policies and mechanisms to address specific policy problems. However, the reform of the municipalities (cities, towns, and villages) in Japan, the level of government most proximate and familiar to citizens, is central to the aspirations of local grassroots movements in the effort to turn them into veritable driving forces behind the process of renewal and innovation of the democratic system in Japan. Japan's decentralization reforms took place in 2000, and since their implementation, the debate has focused on a second phase of decentralization reform, this time aiming for the redistribution of authority and resources at the national level. Of equal importance is municipal reform, to transform municipalities into venues of citizen self-governance. This section focuses, therefore, on initiatives toward the goal of a citizen municipality. ${ }^{2}$

The concept of a citizen municipality was first introduced in Japan in 2005 at the Citizens and Councilors Conference for the Creation of Municipal Ordinances, which has been held every year since 2001. In his recent publication Harumi SUDA (2005), a veteran activist in the citizens' movement and initiator of multiple social initiatives, defines a citizen municipality as a municipality which has a communal framework depending on its citizens, relies on "rules of civil society," and supports citizens in solving problems of communal life. He describes this type of municipality as "the familiar 'first government' in which citizens assume responsibility." Suda emphasizes the importance for the municipality to commit to "rules of civil society," which need to be based on citizens' common sense (SUDA 2005, 44-54; 2010, 128-60).

Local councils are central to the concept of the citizen municipality. Consequently, at the 2007 meeting of the previously-mentioned conference, a new Local Council Reforms Forum was established. At the same

2. Section 3 of this article is based on Tsuвogo 2011b, and has been updated and revised for this publication. 
time, various citizens and individual councilors also run their own initiatives to reform the existing local councils (Hirose and Jichitai Gika KAIKAKU ForUm 2009). After the Tohoku Earthquake of March 11, 2011, the Citizens' Forum for the Creation of a New Society (2011-2012) was integrated into these efforts, with the idea of a citizen municipality as one of its projects. A report was published at the first Citizens' Forum on January $29,2012 .^{3}$

The issue of citizen self-governance is just one matter of contention regarding the establishment of a citizen municipality, the main challenge here being the realization of a completely new working relationship among citizens, local councils, and the mayors of the municipalities. Japanese municipalities are organized on the principle of a dualistic representational system; that is, the councilors and the mayors of the municipality are elected in separate elections, and therefore both independently represent the citizens. Of critical importance for the citizen municipality is a set of basic rules to specify the legal framework connecting citizens and the municipality, a clearly stated catalog of government responsibilities, and a framework for deliberations that are open to anyone. Furthermore, a citizen municipality requires mechanisms to review the policies and projects of the municipality in order to secure necessary financial resources. Matters of social justice and diversity are a central concern, and a citizen municipality needs to aspire to turn itself into "an exemplary social organization" (SUDA 2005, 43-54; Tsubogo 2011b, 106-20). This entails the establishment of a framework for consensus-forming through deliberations and participation, as well as a participatory system of policy formulation.

So far, citizen participation in the process of policy formulation at the municipal level has been limited for the most part to participation in citizen conferences, in which the committee members are recruited from the public. However, starting from the second half of the first decade of the twenty-first century, new methods of participation have been implemented, aiming for participation across generations and diverse groups of citizens, such as citizen discussion meetings in which participants are selected by random sampling. Petitions and appeals have been used to encourage citizen participation on local councils, though these methods have not proven to be sufficient. The successful implementation of a

3. Note that the author also participated in the citizens' municipality proposal, the establishment of the Local Council Reforms Forum, and the activities of the Citizens' Forum for the Creation of a New Society. 
system for policy formulation within a participation-type of framework requires further promotion and support by citizen activity groups.

\section{INITIATIVES FOR RESTRUCTURING THE MUNICIPALITY}

This section takes a closer look at the movement to reform municipalities from the perspective of the citizen municipality concept, particularly from 2000 onwards, that is, after the implementation of the decentralization reforms of 2000 (Tsubogo 2011b, 107-20; Hirose and Jichitai GikaI KAIKAKU FORUM 2009 to 2013). It is currently an open question to what extent the ongoing efforts at the local level serve to improve or implement "rules of civil society," or in what specific ways they conform to the idea of a citizens' municipality. However, as mentioned earlier, fundamental rules that regulate the complex relationships between citizens and the municipalities must be established, based on the needs and the local character of the communities. This implies a departure from the present situation in Japan, where mostly uniform rules are applied throughout the country. The most important developments in this respect can be summarized as follows.

First, Niseko Town, Hokkaido, was the first municipality to enact a Machizukuri (City Enhancement) Basic Ordinance, in December 2000. The scholar Masaru Kanbara has pointed out that the significance of this basic ordinance lies in the fact that it strongly relies on the practical implementation of information sharing and citizen participation. According to Kanbara, another merit of this basic ordinance is that it has incorporated the experiences of the reform movements of other pioneering municipalities since the 1970s (Kanbara 2008, 2-4). Municipality basic ordinances define the foundational principles and rules for the management of a municipality, such as citizen sovereignty and self-governance, information disclosure, citizen participation, the administration's policies and its internal organization, assemblies, administrative procedures, external audits, the ombudsman, and referendums. In that sense, they have also been referred to as "municipal constitutions," being the most fundamental of the municipal ordinances. According to a survey of the Local Council Reforms Forum, as of 2013, such basic ordinances have been enacted in 323 municipalities, or about 20 percent of all municipalities (Hirose and Jichitai Gikai Kaikaku Forum 2013, 134).

Second, the council system is an indispensable component within the process of a municipality's decision-making. Nevertheless, there remain many challenges with regard to making the local councils venues for deliberation, and in effecting reforms to encourage citizens' participation in the 
assemblies. Therefore, in addition to the matter of municipality basic ordinances, initiatives are underway to enact local council basic ordinances. This includes demands for decreasing the councilor quorums as well as reducing councilors' remuneration, and a shift to a citizen participationtype assembly. The first local council basic ordinance of this type was enacted in Kuriyama Town, Hokkaido, in May 2006. According to the Local Council Reforms Forum, as of August 27, 2013, similar ordinances have come into effect in 450 municipalities, or approximately 25 percent of the municipalities surveyed, and the number is increasing (http://www .gikai-kaikaku.net/gikaikaikaku_kihonjourei.html).

Town Council Briefing Sessions have played an important role in the implementation of reforms in the Kuriyama Town Council. Here, the councilors report on the activities of the assembly and hear the opinions and proposals of the town's citizens. To promote deliberations in the Town Council, a procedure of "one question, one answer" is defined by ordinance for questions to the mayor, including the right of a question in return. The Kuriyama Town Council Basic Ordinance provides for the establishment of a new General Meeting where councilors and citizens exchange opinions.

Third, there are also examples of the local council as the driving force behind the establishment of a municipality basic ordinance, e.g., the Citizens' Conference for a Municipal Constitution in Iida City, though in many cases the initiative was with the city mayor. This conference, active from 2004 to 2006, relied on publicly recruited citizens and was directly affiliated with the City Assembly. The Iida City Assembly also held assembly briefing sessions co-sponsored by the machizukuri committee, an important institution of self-governance. The same assembly has evaluated its administration by relying on a series of cycles for the evaluation of the administration and for approval of the settlement of accounts and budget requests. When implementing these cycles, the assembly particularly considers their consistency with the overall political agenda (Basic Concept) of the municipality (ETŌ 2012b, 131).

The implementation of a local council basic ordinance not only promotes communication between councilors and citizens, it also stimulates free and open debate between councilors in the assembly, and creates additional opportunities for citizen participation in the assembly. Currently, there is an immense shortage of policy information. It is also vital to provide support for policy-related legal affairs by hiring more staff in the assemblies' secretariats. In addition to the disclosure of information on the administration, an assembly also must independently gather policy information, relying on the participation of citizens, as well as experts, in the 
assembly's policy-creation process. For example, in Aizuwakamatsu City, Fukushima Prefecture, a basic ordinance was enacted in 2008. This ordinance introduced a multi-faceted framework of meetings with citizens, committees on public relations, public hearings, and policy discussion meetings in order to stimulate a process of policy formation that incorporates active citizen participation (HIROSE and JichITAI GIKAI KAIKAKU ForUm 2010, 13-20; Eтō 2012c). Similar to the steps taken in Iida City, the Aizuwakamatsu assembly also provides for evaluation of its administration and policy plans. There are some assemblies that aim to become, in practical terms, "a full year assembly," contrary to the common practice of relying on multiple short-time session periods within a single election cycle (Hirose and Jichitai Gikai Kaikaku Forum 2013, 190-203).

Fourth, since the 1970s, in efforts led mainly by their mayors, municipalities have been engaged in developing policies for citizen participation and the introduction of basic concepts and basic plans. So far, there have been conferences that consisted mainly of the representatives of various groups in local communities, including some public recruitment of citizens, as well as conferences made up entirely of publicly recruited citizens. Since the 199os, as in the case of Niseko Town's Machizukuri Basic Ordinance, or the Basic Plan of Mitaka City, Tokyo, citizens have been participating from the early stages. The case of Mitaka City in 1999-2001 is an example of a basic plan designed from scratch, being determined without any prior agenda. It entailed a partnership agreement concluded between publicly recruited citizens (the Mitaka Citizens' Plan 21 Conference of 375 citizens) and the city mayor. The citizens themselves were responsible for running the secretariat. Following the revisions to the Local Autonomy Law, there were also initiatives for the Basic Concept not to be based on national law, but to be defined by the local council within the respective municipality's basic ordinance.

However, a problem with citizen participation is that it tends to be limited to certain groups of citizens. In terms of age, participation is biased toward senior citizens, and there tends to be little participation by young or middle-aged people. To promote citizen participation among women, the young, and people with disabilities, it is necessary to empower these citizens. The methods of citizen participation, of course, have become increasingly diverse. For example, public hearing mechanisms (public comment) have been established for regulations and other decisions by municipalities. Citizens contribute to important policies through public comment, questionnaires, and deliberative councils. Citizens' Discussion Meetings constitute one of these new methods. These meetings are 
modeled on the Planungszelle (planning cell) method used in Germany. By selecting participants through random sampling, citizen participation can represent a diverse range of participants, its membership reflecting the structure of the local communities. With this model, administrative responsibilities are carried out by an independent committee where participants are divided into groups of about five people. Within a meeting time of two to three days, usually divided into several sessions a day, group members are asked to discuss a specific theme and are then replaced after each session. These discussions are then summarized and published in the form of a "Citizens' Advocacy Report" (Shinotō, Yoshida, and Kobari 2009; Tsubogo 2011b, 114-17; Shinohara 2012).

Fifth, referendums, a characteristic feature of direct democracy, are implemented to supplement the representative system of democracy. Since the mid-199os, initiatives promoting the implementation of referendums have gathered momentum. Respective ordinances have been enacted to enable municipalities to hold referendums on specific problems, such as large-scale public projects. Furthermore, in December 2000, a permanent type of citizen referendum ordinance was enacted in Takahama City, Aichi Prefecture. Following this, municipalities came to include in their basic ordinances and their citizen participation ordinances regulations on whether to enact a permanent type of citizen voting ordinance. To achieve this, an ordinance is expanded to the number of people who can vote in elections and to admit voting rights to foreigners holding permanent residency and those aged 18 years and over (elections usually require voters to be 20 years of age). However, those citizen votes are limited to a consulting function.

Sixth, municipalities aim with increasing frequency to transform themselves into exemplary social organizations with regard to social justice and diversity. Some of the methods proposed to advance participation by a diverse range of citizens have included the implementation of policies to promote a gender-equal society, to achieve a work-life balance, to secure places of work for people with disabilities, to support the lives and employment of young people, and to secure the life security and social integration of senior citizens, as well as the integration of non-Japanese residents. This is the context in which organizations such as the Resident Foreigners Conference and the Children's Assembly were established. Meanwhile, in terms of employment conditions, non-regular employment in Japan has reached 40 percent of all employment, and even the employment of public officials has come to take various forms, with one-third of these positions now classified as non-regular employment. Furthermore, through out- 
sourcing contracts for designated administrators, NPOS and others are now actively participating in policy implementation. Municipalities continue to face the problems of realizing equal pay for equal labor and establishing opportunities for decent work in local communities, creating the need for a public agreement ordinance to define labor conditions, and introducing a comprehensive evaluation bidding system that incorporates social and environmental values.

\section{Conclusion}

The preceding sections have examined the role of civil society, the activities of workers' collectives, and municipality reforms, all of which can be considered examples of how citizens strive to enact innovative means and mechanisms within the democratic structures in Japan.

In a democracy, the role of the civil society sector is to clarify problem areas and identify the issues to be addressed by reforms. Workers' collectives and related citizen activities groups articulate the needs of the citizens, and proactively create business solutions to address these needs. They develop new policies and promote system improvements, relying on the expertise they acquire through implementing these citizen businesses. Moreover, they engage in policy advocacy to help realize these improvements. By establishing and maintaining citizen businesses, citizen activities expand the civil society sector. With regard to this, the introduction of the nursing insurance system and the outsourcing of operations by municipalities are having a huge impact. Outsourcing from municipalities provides citizens' businesses with the necessary financial foundation for their operation; however, by accepting theses commissions, it has been argued that they also end up failing to complete the original mission. Meanwhile, the ongoing municipality reforms help to strengthen citizen participation in the process of local policy making. This development contributes significantly to the implementation of innovation in Japanese democracy.

With respect to strengthening civil society, at its July 2011 meeting the Council on the Promotion of the New Public Commons identified the possibility of "contracts between government and the civil society sector" as an important issue to be investigated further, along with questions such as how the current corporate system can be adapted to support the New Public Commons, and how to deal with the problem of dormant bank deposits (http://www5.cao.go.jp/npc/pdf/tyousakai-houkoku.pdf). Social enterprises are engaged in business activities that contribute to the tackling of 
social problems and provide meaningful services to the community. Nonprofit social cooperatives increasingly provide options for employment.

At this point, the introduction of a system for new investment-type, small-scale nonprofit corporations poses another challenge. Moreover, dormant deposits in Japan mount up to significant sums of idle funds, and consequently the question has been raised of making them available for financing social and other services. Under the current government of Prime Minister Abe Shinzo (since 2012), deliberations have been taking place in the Committee to Promote Mutual Aid in Society.

It will take time for these measures to be implemented successfully and bear concrete results. Toward that goal, it is necessary for citizen activities and businesses to be supported in local communities, that policy advocacy initiatives of NPOs be encouraged, and that reform efforts within the municipalities be stimulated further. 


\section{REFERENCES}

Benz, Arthur, and Yannis Papadopoulos

2006 Governance and Democracy. New York: Routledge.

Eтō, Toshiaki

2013 Gikai karano seisaku saikuru no dōko to kadai (Trends and issues from assemblies to policy cycles) (3). In Governance, November and December issues 2012, January issue 2013.

2012C Gikai karano seisaku saikuru no dōko to kadai (Trends and issues from assemblies to policy cycles) (2). In Governance, November and December issues 2012, January issue 2013.

2012b Gikai karano seisaku saikuru no dōko to kadai (Trends and issues from assemblies to policy cycles) (1). In Governance, November and December issues 2012, January issue 2013.

2012a Jichitai gikai-gaku: Gikai-kaikaku no jitsusen shuhō (Local council studies: Practical methods of assembly reforms), Tokyo: Gyosei.

HoECKER, Beate, ed.

2006 Politische Partizipation zwischen Konvention und Protest. Opladen: Barbara Budrich.

Hirose, Katsuya, and Jichitai gikai Kaikaku forum, eds.

2009-2013 Gikai kaikaku hakusho (Assembly reforms white paper; 2009 edition, 2010 edition, 2011 edition, 2012 edition, and 2013 edition). Tokyo: Seikatsusha.

IsHige, Eiko

2011 NPO, Workers Collectives to shimin rodō (NPO, workers' collectives and citizens' labor). In Tsubogo and NaKAmura, eds., 194-212.

Ishige, Eiko, Harumi Suda, and Minoru Tsubogo, eds.

2009 Shimin ga egaku Shakai-zō: Seisaku risuto 37 (An image of society drawn by citizens: Policy list 37). Tokyo: Seikatsusha.

Kanbara, Masaru

2008 Jichi-gikai kihon jorei: Jichitai unei no sentan o hiraku (The self-governance and local council basic ordinance: Opening up the frontiers of municipality management). Tokyo: Kōjinnotomosha.

Kersting, Norbert, ed.

2008 Politische Beteiligung. Wiesbaden: Verlag für Sozialwissenschaften.

Koolmann, Jan

2002 "Governance: A Social-Political Perspective." In Participatory Governance, B. Gbikpi and J. R. Grote, eds., 71-96. Opladen: Leske+Budrich.

Matsushita, Keiichi

2005 Jichitai saikōchiku (Restructuring municipalities). Tokyo: Kōjinnotomosha. 
Miyagi, Kenichi

2003 Shimin seiji o hiraku (Opening up citizens' politics). Kenichi Miyagi, posthumous works memorial edition. Tokyo: Miyagi Kenichi Ikōshū Henshū Iinkai.

Nanz, Patrizia, and Miriam Fritsche

2012 Handbuch Bürgerbeteiligung. Verfahren und Akteure, Chancen und Grenzen. Bonn: Bundeszentrale für politische Bildung.

NÈve, Dorotehèe de, and Tina Olteanu, eds.

2013 Politische Partizipation jenseits der Konventionen. Opladen: Barbara Budrich.

OKadA, Yuriko

2013 "Konnan o kakaeru hitotachi to no kyōdō o mezashite (Aiming to work together with people with difficulties: Work site report [1]). In Tatakau shakaiteki kigyō (Social enterprises that fight: Bearing the responsibility for community empowerment), Atsushi Fujii, Kouki Harada, and Kendō Ōtaka, eds., 208-24. Tokyo: Keisoushobou.

Putnam, Robert D.

2000 Bowling Alone: The Collapse and Revival of American Community. New York: Simon \& Schuster.

1993 Making Democracy Work: Civic Traditions in Modern Italy. Princeton: Princeton University Press.

Seikatsu Club

201321 Seiki josei shimin no "kibō no soshikika" (Organizing the hopes of 21stcentury female citizens: Joint buying movement society, final report). Tokyo: Seikatsu Club, Kanto Metropolitan Area Regional Collective, Citizens Sector Policy Organization.

Seikatsu Club Tokyo

2013 Wākingu peipā. Shakai no naka no Seikatsu Club: Rekishiteki giron. (Working paper on Seikatsu Clubs within society: A historical discussion). Tokyo: Seikatsu Club Consumers' Cooperative Tokyo.

SHINOHARA, Hajime

2004 Shimin no seijigaku: Togi-demokurashi to wa nanika (Citizens' political science: What is deliberative democracy?). Tokyo: Iwanami Shoten.

Shinohara, Hajime, ed.

2012 Togi demokurashi no chosen: Mini paburikkusu ga hiraku atarashii seiji (The challenge of deliberative democracy: New politics through minipublics). Tokyo: Iwanami Shoten.

SHinotō, Akinori, Sumio Yoshida, and Kenichi KobARI

2009 Jichi o hiraku shimin togikai: Hirogaru sankaku jirei to hōhō (Citizens' deliberation meetings are opening up self-governance: Extending participation and examples and methods). Tokyo: Imagine Publishing. 
SudA, Harumi

2010 Suda Harumi sairoku 2: Shimin jichitai (Selected records of Harumi Suda 2: The citizens' municipality). Tokyo: Seikatsusha.

2005 Shimin jichitai: Shakai-hatsuten no kanōsei (The citizens' municipality: The possibility of social development). Tokyo: Seikatsusha.

Tsubogo, Minoru

2011 b Bunken jichi to shimin jichitai e no michi (The path to self-governance, decentralization, and the citizens' municipality). In Tsubogo and NAKAmURA, eds., 102-20.

2011a Atarashi kōkyō kukan to shimin shakai no kyōka no kadai (The new public space and issues for strengthening civil society). In Tsubogo and NAKAMURA, eds., 15-51.

2007 Doitsu no shimin jichitai: Shimin shakai o tsuyoku suru hōhō (The citizens' municipality in Germany: A method of making civil society strong). Tokyo: Seikatsusha.

Tsubogo, Minoru, ed.

2009 Hikaku seiji sanka (Comparative political participation). Kyoto: Minerva Shobo.

2006 Sanka gabanansu: Shakai to soshiki no unei-kakushin (Participatory governance: Innovation in the management of society and organizations). Tokyo: Nihon Hyōron Sha.

2003 Atarashi kōkyō kukan o tsukuru: Shimin katsudō no itonami kara (Creating a new public space from managing citizens' activities). Tokyo: Nihon Hyōron Sha.

Tsubogo, Minoru, Gesine Foljanty-Jost, and Koichiro Agata, eds.

2009 Bunken to jichitai-saikōchiku: Gyōseikōritsuka to shimin sanka (Decentralization and municipality reform: Administrative efficiency and citizen participation). Tokyo: Horitsu Bunkasha.

Tsubogo, Minoru, and Keisuke Nakamura, eds.

2011 Atarashi kokyo to shimin katsudō, rōdo undo (New public commons, citizens' activities, and the labor movement). Tokyo: Akashi Shoten.

WNJ

2013 Chiiki saisei ni mukete. Nettowāku de tsukuru atarashi kōkyō. Wākāzu korekutibu ga mushubu chiki no en en en (Toward the regeneration of local communities: "The new public commons" made via networks that connect to local workers' communities of relations! circles! support!). (The $10^{\text {th }}$ Workers' Collective Nationwide Council Executive Committee, held November 2011).

WoCo KanAgawA

20082008 Nenban Kanagawa: WoCo Jitsutaichosa Hōkokusho (Kanagawa Workers' Collective report on the survey of actual conditions, fiscal 2008 edition). 
WoCo Kanagawa and Fukushi Club

20082009 nenban WoCo Shimin hakusho: "Mō hitotsu no keizai" o hiraku to "mō hitotsu no hatarakikata" (Kanagawa Workers' Collective Federation and Welfare Club Consumers' Cooperative, Workers' collective citizens' white paper fiscal 2009 edition: Opening up "one more economy" and “one more way of working”).

YAMAguchi, Yasushi

2004 Shimin shakai ron: Rekishiteki isan to shin-tenkai (Civil society theory: The historical legacy and new developments). Tokyo: Yuhikaku.

YAMAOKA, Yashinori

2011 Nihon ni okeru shimin shakai soshiki no genjō to kadai: Seidoteki kiban o chushin ni (Current conditions in and issues faced by civil-society organizations in Japan: Centered on systemic foundations). In Tsubogo and NAKAmura, eds., 52-72.

YокотА, Katsumi

2002 Orokana kuni no shinayakana shimin: Joseitachi ga hiraita tayōna chōsen (Flexible citizens in a foolish country: Various challenges opened up by women). Tokyo: Honnoki. 